\title{
Entrevista: Ismail Xavier
}

\author{
Entrevistadores: \\ Adriano Saturnino dos Santos \\ Cléver Cardoso T. de Oliveira \\ Úrsula Passos de Paula
}

Para a terceira edição da Revista Humanidades em Diálogo, entrevistamos o professor e crítico de cinema Ismail Xavier. Graduado pela ECA-USP em cinema em I970, mestre e doutor pela FFLCH-USP em Teoria Literária e Literatura Comparada, doutor pela New York University, o professor Ismail Xavier realizou seu pós-doutorado também na New York University e obteve sua livre-docência em USP em I989, sob o título Alegorias do Desengano. Na presente entrevista, ele nos fala sobre a ligação do cinema às demais manifestações artísticas, a inserção do curso de cinema na universidade e a dimensão política da sétima arte. 


\section{Autonomia do cinema?}

Humanidades em Diálogo: Diversos autores como André Bazin, Gilles Deleuze e Jacques Aumont pensaram a arte cinematográfica relacionando-a com outras disciplinas, tais quais a literatura, o teatro, a filosofia e a pintura. Como o senhor analisa essa apropriação feita pelos pensadores do cinema e em que medida seria possível compor uma teoria cinematográfica autêntica? É da pretensão do pensamento cinematográfico ser completamente autêntico, ou seja, aspirar a uma pureza que não o desvencilhe dessas disciplinas, mas o caracterize como pensamento autônomo?

Ismail Xavier: $O$ cinema tem essa particularidade de ser uma arte de que se conhece o momento em que ela emerge em sua forma canônica, ao contrário das mais antigas. Desde esse período de emergência, final do século XIX e início do século XX, há um posicionamento da crítica, dos próprios realizadores e de alguns intelectuais que procuram defender o cinema como arte do ponto de vista conceitual. Há opções nisto, pois alguns aproximam a reflexão sobre cinema de tradições que pensavam a questão da narrativa e do drama (referindose à literatura e ao teatro); outros aproximam o cinema das artes plásticas e da música. E você tem um leque muito grande de teorias conforme a prioridade trazida pelo autor. De lá para cá, isso continuou. Há aspectos da teoria do cinema que estão inseridos nas questões relacionadas com a narrativa enquanto forma de organização do tempo, representação de ações e eventos que também pode se dar com outros suportes: texto escrito, história em quadrinhos, teatro. Por outro lado, se você pensa a questão do cinema no interior da estética, você vai ter uma reflexão que o articula com as outras formas de arte: a pintura, por exemplo. E pensar a questão do cinema a partir de outros recortes, como a do documento histórico, pode também gerar contato com problemas que não são propriamente estéticos. A gente tem uma tendência a trabalhar com a ideia do cinema no singular: o cinema! Quando, na verdade, seria quase como querer trabalhar a ideia de unificar uma teoria sobre o campo do texto escrito; em verdade, há um leque muito amplo de usos e de gêneros que solicitam formas de análise distintas com instrumentos distintos.

Dado o fato de que na experiência cotidiana o cinema se confunde com aquele momento em que você paga o ingresso, entra numa sala e assiste ao filme, a gente tende, de imediato, a identificá-lo com o espetáculo e a narrativa de ficção - esta é uma forma de uso muito particular da técnica cinematográfica (ou videográfica). Tomando a captação de imagem e som, e a montagem, em seu sentido mais amplo, temos claro que é preciso, antes de tudo, pensar esta variedade de relações entre tecnologia e linguagem, estas escolhas possíveis no trato de certo material e também trabalhar a noção de 
estilo, pois esta se define justamente nas formas de trabalhar a matéria de base que constitui uma prática artística (no caso do cinema, o trabalho com a câmera, a montagem, o som). É como no campo da linguística, onde tenho a possibilidade de montar um quadro conceitual para pensar a língua e suas estruturas fundamentais, mas devo, por outro lado, pensar a questão do uso da língua em várias situações de comunicação que vão definir, cada qual, um recorte conceitual completamente diferente. Uma coisa é você discutir um texto de um historiador, outra é discutir uma reportagem de jornal, e outra ainda é discutir poesia. Claro que tudo isso poderá ser conectado, mas de qualquer maneira é nítido que cada um destes terrenos tem a sua configuração própria e terá que ter uma reflexão própria. Cinema é a mesma coisa, e seu processo técnico (falo aqui do período da fotoquímica, pois a imagem digital altera este quadro) possibilita uma prática e a composição de imagens que denominamos de "índices", além daquele aspecto icônico bem preciso na reprodução das aparências; índice porque a luz se imprime na película como um rastro do objeto que esteve em certo momento diante da câmera. Temos, então, essas duas coisas juntas (o índice e o ícone), o que envolve toda uma reflexão sobre o problema da conexão entre o cinema e o real. Temos um artefato que, em primeira instância, parece um documento que aponta para um referente fora dele. Essa dupla conexão com o que está fora da imagem tem implicações epistemológicas. Se você é um historiador e está diante de uma foto ou de um filme, você vai fazer aquilo que você faz diante de qualquer documento, ou seja, um exame crítico que inclui a análise de como aquilo foi produzido e quais foram as condições que o tornaram possível. Você não pode ser ingênuo no sentido de ver na imagem a verdade, uma impressão direta do mundo, você sabe que aquilo é um artefato que foi produzido de uma determinada forma, você tem que analisá-la.

Se você quer trabalhar com a questão da imagem na sua capacidade de representação dentro de um campo que envolve toda a história das artes visuais, você vai ter outro tipo de problemática: como trabalhar com o que é comum à fotografia, ao cinema, à pintura e à gravura? E idem com relação ao fato de que no cinema as imagens vão compondo uma sucessão temporal que pode ou não se estruturar como uma narrativa e compor um drama, ou também pode explorar outras direções. Desse modo, você tem diferentes campos de debate, de construção conceitual, que vão ser articulados. Isto leva aos posicionamentos de diferentes autores. Um eixo de oposição que se reitera na discussão sobre os filmes é a questão da montagem ou não montagem; alguns defendem um tipo de uso, construção, apoiado na justaposição de imagens separadas pelos cortes (um espaço tempo sintético que o cinema constrói), outros defendem a força imediata do registro indicial e das qualidades próprias da imagem na sua duração e continuidade. Há um amplo espectro de pressupostos teóricos e há a 
afirmação de valores própria à situação em que a nossa relação com o objeto é de caráter estético. Eu percebo que vocês estão preocupados com a questão desse diálogo entre o cinema e os outros campos, o que é sem dúvida central. Você não pode trabalhar com a ideia de construir uma teoria do cinema entendida como um campo conceitual isolado que pode ser trabalhado apenas com um instrumental teórico que lhe seria específico e que traria uma coerência interna à teoria voltada para este objeto. A abordagem do cinema envolve um esforço interdisciplinar (desculpem-me pelo clichê, mas não tem jeito).

Eu poderia citar alguns momentos em que houve da parte de teóricos o impulso de privilegiar a especificidade, de encontrar aquilo que é próprio ao cinema e que lhe dá um campo exclusivo de significação, de expressão. Isso foi muito forte no começo da reflexão sobre o cinema lá por volta da Primeira Guerra Mundial, porque ali havia a necessidade de afirmar o cinema como arte e, portanto, era necessário dizer que o cinema não era teatro, literatura, música, artes visuais, pintura. Não por acaso vocês conhecem esta expressão: "sétima arte", ela foi construída nesse primeiro momento. Existe o manifesto do italiano que morava em Paris, Ricciotto Canudo, publicado em IgII, que construiu um sistema para encaixar o cinema na história da arte. Sétima arte por quê? Porque existiam as artes do espaço, que para ele eram a pintura, a escultura e a arquitetura, e as artes do tempo, a música, a dança e a poesia, sendo o cinema a sétima, que é a arte do espaço e do tempo, a grande síntese. Percebem que é um sistema em que não há lugar para a referência à narrativa literária nem ao teatro, exatamente os dois campos que, segundo os que eram considerados os "detratores" do cinema, eram o dado principal e o cinema não faria outra coisa além de incorporá-los, fazendo um teatro filmado, ou uma narrativa por imagens cujos princípios estavam já dados pela tradição literária. Então, você vê que Canudo expulsou do esquema geral das artes justamente a literatura e o teatro e montou essa figura da "sétima" que trazia aquele ponto de síntese: o cinema. Há, na história do cinema, uma tensão muito grande entre esta busca do específico e os posicionamentos teóricos que acham que essa ideia da especificidade não se sustenta, que uma teoria do cinema no singular não se sustenta. No mundo acadêmico, a partir dos anos 60 para cá, quando se incorpora o cinema como uma área de trabalho, uma área de estudos, uma área de formação, essa questão volta. Já que o cinema é uma área que está sendo incorporada, como defini-la e como lhe dar consistência para que ela reivindique o seu lugar? Foi um pouco a mesma coisa: lá nos anos 20, a questão era o lugar do cinema no sistema das artes; agora, a partir dos anos 6o, a questão é o lugar do cinema como um campo de reflexão teórica que reivindica um espaço no campo universitário.

Houve, dentro das oscilações pendulares, sempre um movimento de pensar o específico, mas ao mesmo tempo não ser tão radical na tentativa 
de isolar um campo; por exemplo, no caso do André Bazin, que teve um papel muito forte porque, apoiado na fenomenologia, naquele período pós-Segunda Guerra, ele fez a defesa da imagem contínua em sua duração, dizendo que o específico do cinema está em sua capacidade de compor um molde do mundo que oferece uma percepção das ações e dos acontecimentos marcada pela ambiguidade, pela nossa relação com um ser humano inserido no espaço e no tempo, o dito "homem em situação" às voltas com escolhas num mundo em que há indeterminações. O específico no cinema seria aquele realismo de base, pois a melhor escolha do artista é caminhar na direção que potencializa as propriedades do meio. Privilegiando a ideia da duração, a ideia de minimizar a montagem, de evitar a descontinuidade, ele fez uma inversão, num momento em que havia a ideia de que o específico do cinema era a montagem; o fundamento da criação e da produção de significados estaria na combinação de imagens separadas pela descontinuidade do corte (Eisenstein é a figura paradigmática nesta direção). Em todos os momentos da história do cinema, você vê que há uma espécie de duplo esforço: de um lado, marcar uma ideia da especificidade que gera uma estética ou privilegia um modo de trabalhar com as imagens (às vezes quando eu falar em imagens vão estar implícitos aí os sons, às vezes fica chato ficar repetindo "imagens e sons, imagens e sons..."); de outro, existe o entendimento do que seja o diálogo com as outras áreas. O Bazin nos anos 40-50 tinha o seu próprio entendimento, e Eisenstein nos anos 20-30 tinha o seu; ambos trabalharam bastante a questão. Nos anos 60 e 70, no plano acadêmico, tivemos a tentativa de criar um campo teórico unificado e com uma coerência interna suficiente para justificar a disciplina, no caso brasileiro com a tendência a se inserir o cinema no campo das comunicações: este é um gesto que não foi inocente, é um gesto que influiu no futuro dos estudos de cinema no Brasil, dadas as tensões entre os que dão ênfase à comunicação e os que dão ênfase à estética. Como observei, minha postura é de conceitualmente trabalhar a partir da ideia de que o cinema partilha, com outros suportes, determinadas possibilidades e propriedades. Ou seja, os destinos do pensar o cinema são inseridos nos destinos do pensar a arte, a comunicação, a História, a contemporaneidade. Nesse plano, você vai reencontrar a mesma constelação de posicionamentos, de entendimentos do que seja a arte, do que seja fazer uma reflexão estética sobre um objeto. Nos últimos vinte anos, houve um adensamento da presença dos filósofos na formulação de uma teoria do cinema, notadamente a partir dos livros de Deleuze, publicados nos anos 80 . Como é próprio à sua démarche como filósofo, há aí a invenção de conceitos (imagem-movimento e imagem-tempo) e uma taxonomia das imagens feita em diálogo com a semiótica de Peirce, claro que sempre com os deslocamentos que fazem sua diferença face aos textos de que se apropria. Ele não escreve sobre o cinema como um objeto exterior 
a que sua filosofia se aplica. O cinema é parte constituinte do movimento da filosofia, pois os filmes pensam, conduzem de formas bastante ricas uma indagação sobre o mundo feito imagem. Há muitas respostas a Deleuze, como as de Jacques Rancière e de Alain Badiou. Na tradição dos teóricos e críticos já militantes na área, surgiu uma enorme bibliografia e Jacques Aumont, citado por vocês, tem um livro que se chama Em que pensam os filmes?, como parte de uma série de textos, artigos, voltados para essa questão do pensar inscrito no próprio dinamismo das imagens. A imagem em movimento teria esta força, e não só no plano restrito dos processos cognitivos, mas naquilo que envolve todas as potências de nosso psiquismo. Um ponto central é a questão da formação das imagens em movimento como modos de estruturação do tempo no plano das ações e do próprio pensar. A discussão do cinema está hoje muito marcada pelo debate filosófico, enquanto que nos anos 60 e 70 , havia uma hegemonia das categorias de caráter sócio-histórico no debate sobre as opções dos cineastas.

O que é interessante é que, em cada um desses momentos há a mesma pergunta: como fica a relação entre cinema, literatura, teatro, música e pintura? Só para dar um exemplo que envolve a pintura e que repõe Jacques Aumont na conversa, temos o seu livro, O olho interminável, em que critica - e eu concordo com ele nesse ponto - a ideia de que a relação entre cinema e pintura se faz na medida em que os cineastas e os fotógrafos tratam de citar a pintura ou de incorporar estilos pictóricos e dialogar com determinado pintor já consagrado na história da arte, como se isto fosse um gesto de, digamos, sofisticação ou de adensamento da expressão. Esta é uma maneira equivocada. A questão do cinema, pintura e outras artes tem que sempre ser colocada numa dinâmica que as envolve a todas numa problemática dentro da qual elas interagem. Tal problemática não é própria a nenhuma delas; engloba a todas.

Humanidades Em DiÁlogo: O senhor falou da consolidação do cinema como disciplina dentro do meio acadêmico brasileiro. Ainda dentro desse espectro, como o senhor vê a relação dos cursos de comunicação - especificamente o de cinema - com outros cursos dentro da universidade?

ISmail XAVIER: Se você insere o cinema na área de comunicação, privilegia a ideia de que existe um sistema mais geral que, embora inserido num processo cultural, econômico e político, tem a sua especificidade e exige uma conceituação que não é a mesma do sociólogo, do historiador, e que vai recortar o campo segundo um ângulo original dando conta de aspectos que não seriam contemplados por outras disciplinas das áreas de humanas. E se você busca essas categorias capazes de dar conta de certo dinamismo que ocorre na televisão, 
no jornalismo e no próprio cinema, você busca categorias muito amplas que abarcam todos os meios. Essa é uma maneira de trabalhar e, dentro dela, existem algumas polêmicas, como a que aconteceu quando surgiu no mundo anglo-americano o chamado cultural studies, a partir da escola de Birmingham. $\mathrm{O}$ pensamento dos frankfurtianos havia definido o primado da produção na ideia de indústria cultural: é a produção que comanda o dinamismo do sistema, dentro de um pressuposto marxista. O cultural studies veio para questionar isso ou, pelo menos, introduzir certas nuanças no processo, dando ênfase aos mecanismos e às condições de recepção dos produtos que a indústria joga no mercado. De um lado, temos um pensar o conceito de indústria cultural a partir do pressuposto de que a produção não é apenas de objetos, mas também de sujeitos que vão consumir esses objetos. De outro, temos os estudos culturais que acentuam que tais sujeitos estão inseridos em outros circuitos, em outras redes, em outras mediações que vão gerar a possibilidade de que a recepção não seja determinada pela produção, não corresponda ao desejado pelo sistema. $\mathrm{O}$ que interessa nesta perspectiva é estudar a maneira como os diferentes grupos sociais, diferentes etnias, diferentes nacionalidades se apropriam daquilo que o sistema produtor na mídia lhes oferece para uma interpretação que em princípio gera algo novo. Essa polêmica entre cultural studies e a Escola de Frankfurt é um dos campos bem nítidos no qual o debate das comunicações está mobilizado. É uma das polarizações do campo que vale a pena discutir. Por outro lado, do ponto de vista da área em que eu estou, há um movimento que parte da questão do cinema para chegar a essas outras questões mais amplas, que incorpora o debate mais amplo, mas o atravessa com perguntas que emergem do próprio campo estudado. Você tem que dar conta de casos específicos que fazem parte da constelação que cabe a você explicar melhor do que ninguém: filmes particulares, autores particulares, contextos particulares, às vezes com percursos em que os conceitos gerais não operam. O mesmo se pode dizer quando se pensa a inserção do cinema no campo das artes, pois aí também se dá esta tensão entre o geral e a feição própria que as questões adquirem no campo específico.

Se você pensar o cinema incorporado na universidade dentro de um instituto de artes (que não é o caso da USP), você vai privilegiar, na formação do aluno, uma discussão em que haverá uma hegemonia das categorias estéticas que estão sendo pensadas para discutir particularidades do processo literário, teatral, das artes visuais, da música. Se você quer pensar o cinema popular e a televisão (novela, por exemplo), você tem de referir o seu estudo à história do teatro, do melodrama, por exemplo, que é um gênero específico e central neste processo. Há uma série de questões que já estão pensadas a partir de determinadas categorias ligadas à história das artes, do teatro e da literatura, que permitem pensar esses gêneros da mídia a partir de um recorte que dá 
conta da maneira como eles se transformaram para chegar a ser o que são hoje, explicando muito da força que eles têm dentro do processo cultural e social.

A gente sabe que, para uma pessoa que está se formando como realizador de cinema, é muito mais importante ela ler romances, conhecer teatro, ter uma relação forte com as artes visuais e educar o seu olhar no contato o mais intenso possível com o imenso repertório da história da pintura e da escultura, do que seguir um preceito positivista de que o realizador, no campo da mídia, é como um engenheiro que aplica a ciência básica para fazer seus projetos. Um projeto de cinema não é teoria da comunicação aplicada. É um projeto que se apoia na experiência integral de seus autores, algo que passa pelo conhecimento, sensibilidade estética, erudição histórica.

Nos cursos de literatura, a situação é diferente, pois se pensa no aluno como futuro professor, pesquisador, crítico literário. A questão da formação do poeta ou do romancista não está no centro. Se no processo surge um romancista, ou um poeta, isso é um efeito colateral, digamos assim. No caso do bacharelado em artes plásticas, tal como no cinema, temos uma série de atividades práticas que vão auxiliar na formação de um artista, como na música e no cinema. E essas formações são tanto mais ricas quanto maior for o diálogo entre as várias artes, coisa que, na ECA, não acontece no grau em que deveria. Os currículos, por exemplo, são completamente separados.

Humanidades em DiÁlogo: Mas dentro do próprio curso de cinema parece que não há interesse dos alunos em estudar a teoria do cinema, em "pesquisar" sobre o cinema, visto que há oferta de disciplinas que buscam tal debate por parte dos docentes, mas não há interesse de grande parte dos discentes. Parece que os alunos estão muito mais interessados em fazer cinema do que pensar o cinema. Do mesmo modo que o senhor falou que no curso de letras você forma professores de literatura, críticos literários e ...

ISMAIL XAVIER: ...pesquisadores e historiadores...

HumANIDADES EM DIÁlOGO: ...você não forma necessariamente romancistas...

ISMAIL XAVIER: ...ou poetas.

Humanidades em Diálogo: No curso de cinema, é o contrário. Você forma...

ISMAIL XAVIER: ...diretores, fotógrafos, montadores. 
HumanidAdes EM DiÁlOGO: É um curso mais "técnico", profissionalizante, por assim dizer? Por exemplo, o curso de engenharia forma um engenheiro. $O$ curso de cinema forma um fotógrafo que vai saber usar luz, sabe tudo de teoria de cor, mas não sabe escrever um artigo sobre um filme.

ISMAIL XAVIER: Em principio, isso não seria uma obrigação, ou seja, ele pode saber por outros caminhos, por interesse próprio. Mas o curso tem como ênfase a formação do profissional, ou seja, daquele que será o fotógrafo. O que é interessante é qual a atitude dos estudantes diante desse quadro. E ela varia muito. Há estudantes que gostariam de ver esse processo do fazer e do pensar mais articulados, e há estudantes que têm uma tendência a rejeitar a teoria. Isso depende muito. Há turmas que são mais teóricas, outras mais "técnicas". Então, isso depende muito de cada turma e de conjunturas de época. Por razões as mais variadas, há tempos que privilegiam certo empirismo e outros que favorecem um espírito mais reflexivo, dependendo da própria conjuntura do cinema no Brasil: nos anos 60-70, o exemplo do Ginema Novo favorecia a reflexão, a busca da autoria, a mescla de teoria e prática; depois tivemos uma demanda maior de formação técnica específica favorecida por uma expectativa de maior do cinema dito de mercado. De qualquer modo, essa questão de como o aluno responde ao que lhe é oferecido é decisiva, porque, na verdade, não são os professores que fazem o curso, são os alunos e os professores juntos. Em sua pergunta, acredito, vocês estão preocupados com o caso do empirista, daquele que quer se formar profissionalmente e não está querendo maiores especulações. Isso é um dado frequente, e é favorecido porque, também no ambiente profissional, predomina o empirista. Houve épocas em que os alunos formados na ECA encontravam, num setor ou outro da produção, resistência: "Ah!, não, esses caras vêm querer dar muito palpite, vêm querer dar muitas ideias. Eu não quero. O que eu quero é um técnico”. Isso é um problema. Uma maneira de a gente rastrear essa relação é ver quantos formados pela ECA vão para a pós-graduação. E o número não é muito grande. No meu caso, por exemplo, ao longo de quase trinta anos, os alunos da ECA são minoria quando eu olho o elenco dos meus ex-orientandos.

Para encerrar a conversa sobre a formação do cineasta, é bom lembrar que arte não é comunicação, simplesmente. Para ser polêmico, posso dizer: arte é não-comunicação. Arte é desconcerto, desautomatização da percepção, a criação de uma experiência que obriga a repensar o objeto diante do qual você está, repensar os códigos da comunicação, deter-se diante do que está fora do padrão e da rotina; não é o passar rápido os olhos diante do quadro ou do filme. 


\section{Sobre o gosto.}

Humanidades Em DiÁlogo: O senhor disse que a formação do olhar é essencial para um realizador, elencando diversos campos artísticos no qual ela se processa. A formação do olhar está, portanto, conectada com a arte. Já que se pode educar o olhar e, a partir daí, o gosto, é possível falar em uma arte boa e uma arte ruim? Existe o bom cinema e um cinema ruim? Ou a distinção está entre o que é arte e o que não é?

ISMAIL XAVIER: A distinção entre arte de boa qualidade e de má qualidade não está vinculada a distinções de gênero. Um recorte muito comum, no caso do cinema, é aquela ideia: quanto mais um filme está inserido no centro da indústria, mais ele estará limitado a determinados protocolos de criação, condições, valores conservadores, no sentido de que vai apenas ser lugar de entretenimento e de reconhecimento do ritual já estabelecido. A indústria seria o lugar da má qualidade, por oposição aos cinemas alternativos, que seriam o lugar da boa qualidade, da criação, da maior complexidade. A minha posição é de que em todos os gêneros - seja o cinema dentro da indústria, seja o cinema alternativo, seja o cinema de experimentos radicais - há o melhor e o pior. $\mathrm{O}$ fato de um cineasta se colocar no campo da vanguarda não significa que o trabalho dele seja bom por definição. Obviamente, o campo da vanguarda tem coisas fundamentais que realmente fazem a diferença, mas nem tudo o que se insere em sua vertente faz jus a esta inserção. Por outro lado, não posso chegar e falar: "Tudo em Hollywood é fábrica de ilusão, de sonhos, uma máquina conservadora que não faz outra coisa senão cumprir um ritual de reposição dos mesmos valores de sempre”. Não dá para você fazer esse tipo de diagnóstico geral, porque há cineastas e filmes feitos dentro do sistema industrial que têm muito valor. Há filmes dentro da indústria que você e qualquer crítico de cinema consideram importantes, por exemplo, Gidadão Kane. E Cidadão Kane é um filme muito mais complexo, muito mais rico e com uma experiência estética que vale muito mais do que um bom número de filmes feitos segundo o espírito de vanguarda forte, alternativo etc. Não dá para ser monolítico. A minha tendência é dizer o seguinte: há a questão do gosto, palavra que se usa para evocar o que resulta de toda uma formação e em que estou implicado por inteiro, não como um suposto especialista. É neste plano que se define o meu prazer ou desprazer, o gesto de ter encontrado ou não um "bom objeto", no sentido freudiano. A questão do valor da experiência trazida pelo objeto é crucial, pois é a partir dela que eu posso ou não decidir me ocupar dele, analisá-lo. Dispor-se a escrever sobre um filme é algo que depende do impacto inicial, da sedução inicial. No meu caso, na grande maioria das situações, são os filmes do cinema alternativo que me seduzem. Mas não é raro encontrar satisfação e vontade de chegar mais 
perto de determinados filmes que estão dentro da indústria. Portanto, quando vocês me perguntam: "Existe o bom cinema e o resto?", eu não acho bom falar nesses termos. A ideia de resto traz um critério aristocrático no sentido de opor os poucos e bons à massa dos não qualificados. Não é assim. Se assumimos que a qualidade não se espalha assim com facilidade, isto ocorre em qualquer desses campos, na indústria e no terreno do chamado cinema de arte.

\section{Humanidades em DiÁlogo: Essa seria uma pergunta.}

Ismail Xavier: A ideia do cinema de arte emergiu num momento da história do cinema, nos pós-guerra, em parte como etiqueta, classificação que tinha o seu efeito mercadológico. A cada período, conforme a configuração, a dicotomia entre o rotineiro e o alternativo, diferenciado, aparece. Lá atrás, no primeiro momento da crítica do cinema e da teoria nos anos 20 , já havia a distinção entre indústria e vanguarda. $\mathrm{O}$ campo do cinema narrativo-dramático teria adulterado a vocação do cinema, desviando-o de seus caminhos mais legítimos; o surrealismo, o cinema construtivista na União Soviética, o impressionismo na França, o expressionismo alemão, enfim os movimentos do cinema em conexão com a arte moderna se colocaram como a experiência mais legítima onde o cinema encontrava seu caminho. Por sua vez, naquele momento era unânime a celebração do gênio de Chaplin, sua maneira de trabalhar com o moderno, a sua forma de trabalhar com a relação entre o corpo e os objetos. E toda essa invenção chapliniana se deu no interior da indústria. É claro que depois Chaplin teve problemas e pagou um preço alto pelas suas posições políticas. Mas seu problema maior não foi a indústria do cinema, foi a perseguição política durante a Segunda Guerra. Cito exemplo para reiterar a minha crítica às dicotomias muito cerradas que geram dogmatismos.

Humanidades em DiÁlogo: Então, mas daí surge uma dificuldade que foi o motivo da pergunta. Se a gente acha que existe uma formação do olhar, uma formação do gosto, mas, ao mesmo tempo, não se pode ser monolítico, prescritivo. Como vai se dar essa formação? Se o senhor tem o seu gosto, eu tenho o meu e cada um tem o seu, como dizer que existe o bom gosto, ou a formação, o refinamento, da erudição do gosto?

Ismail XAVIER: Vocês fizeram uma pergunta que é complicada. Vamos tentar pensar. Primeiro ponto, quando eu digo que existe essa formação e defino que há sim em todos nós um movimento legítimo de juízo estético, todo trabalho de formação, de realização e de reflexão parte da diferença e oposição de valores. O fundamental é que essa oposição seja trazida à discussão e que cada qual explicite os seus pressupostos teóricos e estéticos, não silencie sobre 
a questão do gosto. Quando eu falo gosto é, para dizer de maneira abreviada, tudo o que diz respeito à constituição do sujeito; nós que vivemos depois da emergência da psicanálise não podemos nos colocar como sujeitos soberanos de seus movimentos, inclusive no que toca às opções conceituais. Claro que não existe a possibilidade matemática de demonstrar por $a+b$ que eu tenho razão, mas a questão do gosto tem seus parâmetros e o melhor caminho é explicitálos porque é desta problematização que surgem as chances de esclarecimento. Quando eu disse que não quero separar um campo da legitimidade e um da ilegitimidade a partir de gêneros, ou a partir da inserção de uma obra no modo de produção, ou de sua recusa desse modo de produção, isto não significa que esteja descartando aquilo que me permite trabalhar (deixando claro o meu critério em cada caso) a distinção do melhor e do pior a partir de um juízo de valor assumido integralmente. Esse juízo de valor tem aspectos conceituais e pode ser fundamentado, mas seria ingênuo supor que essa fundamentação é exaustiva e nos protege de contradições, ambiguidades.

Agora, o fundamental é o seguinte: você tem o direito de gostar ou não do que quiser para uso privado, mas estamos aqui trabalhando com pessoas que estão interagindo numa esfera pública, onde tenho que trabalhar com a ideia de que as razões têm que ser trazidas no debate. Nessa esfera é para debater sim, com todos os problemas que o debate possa trazer. Jamais cortar uma discussão no meio com esse papo de que gosto não se discute. Aquilo que eu tenho como repertório conceitual para pensar a arte vai ser internalizado e vai ser traduzido em uma concepção na minha capacidade de escuta, de olhar, em aquilo que nós estamos chamando de gosto. Portanto, não são coisas que caminham paralelamente e que são independentes umas das outras, é óbvio que o meu repertório incide sobre aspectos da minha sensibilidade, da minha afetividade e da minha reação à arte. Glaro que pode haver dois críticos de arte eruditíssimos, com uma consistência conceitual razoável e que tenham posições opostas em relação a determinados movimentos, determinados artistas, determinadas obras em particular. As razões ditas não esgotam e não dão conta de todos os aspectos que estão por trás do gosto. Porém, de qualquer maneira, elas geram um debate republicano, digamos assim, e esse é o ponto decisivo. Você não pode se isentar diante desse problema do gosto.

\section{Cinema e público}

Humanidades em DiÁlogo: Sempre houve um grande interesse quanto ao diálogo autor-público. Ele sempre se caracterizou como uma grande preocupação, e hoje ainda mais, tendo em vista o progressivo divórcio do público brasileiro com os filmes nacionais (salvo no caso de produções que dialogam com um formato televisivo). Tal debate acerca da comunicação 
do cinema com o público se tornou mais agudo entre o Cinema Novo e o Ginema Marginal: o primeiro, com o intuito de sair do isolamento e buscar maior comunicação com o público, voltava-se, a certa altura, para um estilo mais convencional; o segundo preferia reafirmar a experimentação, recusando concessões. Em que medida é possível compreender a atual resistência do público ao cinema nacional? As expectativas deste público atual são tão diferentes das do público dos anos I970, quando houve um maior interesse do brasileiro pelos filmes aqui produzidos?

ISMAIL XAVIER: Vamos tentar criar um referencial que permita conectar esses tempos diferentes. O cinema desde sempre tem nessa organização industrial um dinamismo que envolve produção, distribuição e exibição; ou seja, produção e recepção, dois polos inseparáveis. Tal sistema tem, de um lado, a capacidade produtiva e, de outro, uma notável organização de mercado, que envolve competência e técnicas das mais variadas de como vender esses produtos e, portanto, criar um discurso publicitário, fundamental para que se chegue com bastante vigor até o receptor, o espectador. Os países periféricos dificilmente conseguiram estruturar, mesmo para seu próprio mercado, esse processo industrial de produção e recepção. Na medida em que essa experiência vai se acumulando, cria-se uma série de efeitos que vão se somando, pois, implantada uma indústria, pela sua própria continuidade e pela sua experiência, ela é capaz de constituir um processo, que é empírico, e não de controle total nem previsível, de repor os seus testes em grande velocidade, o que significa produzir em grande escala e saber onde se errou e onde se acertou, onde se pensou que fosse dar errado e deu certo e vice-versa - tudo do ponto de vista do mercado. Com isso o que se aprende é o seguinte: a força está menos na capacidade de acertar o alvo de imediato e mais no conjunto de bombas que se tem para soltar, já que das muitas lançadas algumas vão atingir o alvo. A indústria tem esse aspecto comparável com o aspecto militar: quando se tem duas bombas nas mãos, cada uma delas é decisiva, um erro é fatal, e isso é grave; quando se tem duzentas, cada uma delas constitui uma aposta pequena no conjunto. Nessa lógica da acumulação de experiência, de competência e de possibilidade de teste, é mais fácil uma indústria que já é hegemônica manter a sua hegemonia do que um grupo emergente, com menos munição e menos recursos, enfrentá-la. Esse mecanismo empírico faz que a experiência ganhe uma importância enorme, e isso vale tanto para os cineastas, fotógrafos, montadores, que trabalham sem parar e acumulam experiência, quanto para o receptor, que, vendo sem parar, também vai se acostumando com certo padrão que ele transforma em natural. Por isso é que a indústria se move, sob pena de correr o risco do desgaste, do esgotamento de uma fórmula. Todo esse dinamismo implica que esse sistema, ao mesmo que tempo que se repõe nos 
seus princípios, muda para enfrentar o desafio de não perder o gancho com os espectadores.

O cinema mexicano foi um dos poucos cinemas da América Latina que atingiram um nível industrial de produção dos anos 40 aos 60 , até entrar em crise - a ponto de eu, na minha infância, ter visto muitos filmes da Pelames, muitas comédias do Cantinflas. Já o cinema brasileiro nunca conseguiu chegar a esse ponto. No grande momento de investimento de capital, que foi a Vera Cruz, industriais paulistas decidiram fazer um cinema de exportação acontecer, julgando-se competentes e aptos a entrar nesse jogo internacional, mas calcularam mal, não tinham experiência e foram ingênuos em achar que basta ter o produto que ele escoa naturalmente - ora, há de se trabalhar a distribuição e controlar os mecanismos, um processo muito mais complexo do que parecia. Então, a Vera Cruz durou quatro anos e meio, e faliu. O que deu certo aqui no Brasil foi o filme de baixo orçamento, que era feito em menor quantidade, com menos recursos e que tinha um público que não era igual ao do cinema norte-americano, mas um público constante: a comédia musical, a dita chanchada. O que garantiu à chanchada essa possibilidade foi que nos anos 40 o maior exibidor de cinema do Rio de Janeiro, chamado Severiano Ribeiro, começou a produzir chanchada. Esse homem detinha as duas pontas: ele produzia e tinha os cinemas. Como era evidente que ele não tinha poder suficiente para desafiar o cinema norte-americano, ele continuou exibindo nos seus próprios cinemas os filmes norte-americanos, mas ocupando uma faixa menor de mercado, inclusive aproveitando que já existia a lei de reserva de mercado. Eis uma explicação boa de como se pode montar uma convivência, que supunha, sobretudo, o reconhecimento da hegemonia norte-americana. Quando chegou a geração do Cinema Novo, havia um debate cultural que envolvia o exemplo do neorrealismo na Itália, a ideia do cinema alternativo, e foi descartada a ideia da indústria; ia-se trabalhar com baixo orçamento e com a invenção de uma linguagem capaz de provocar rupturas - com a esperança de que os espectadores pudessem acompanhá-las - o que não aconteceu. A parcela do público com a qual o Ginema Novo se comunicou foi bem menor do que, obviamente, a atingida pelo cinema norte-americano, mas não tão menor quanto a da chanchada. Pois os filmes do Cinema Novo tinham mais público na sua época do que os filmes brasileiros feitos hoje com baixo orçamento, que têm uma média de 50 a 100 mil espectadores. O Cinema Novo teve o seu público, inclusive suficiente para produzir um retorno com o qual o filme pudesse se pagar; de qualquer modo, era difícil alcançar uma continuidade estável de produção. Constatando esses limites, pelo final de década de 60, os líderes do Cinema Novo montaram essa proposta de alterar a sua linguagem e trabalhar dentro de protocolos mais aceitáveis para o grande público, a fim de se expandir. Isso em parte aconteceu, pois a partir de I969 começam a aparecer 
filmes de grande sucesso, como Macunaíma, e, no início da década de 70, essa proposta cinemanovista de ampliação de público encontrará, a partir de 197374, na Embrafilme o seu instrumento, quando a produção de cinema passa a ser financiada também pelo Estado.

Esse encontro do cinema de esquerda com uma empresa estatal num regime militar foi muito peculiar. O governo, preocupado com a imagem do Brasil no exterior, criou a Embrafilme em I969, tendo em vista a mediação com o mercado externo, não a produção de filmes. Mas havia a constatação de que o bom cinema brasileiro era o de oposição, o do Ginema Novo. A ditadura não encontrou, com uma ou duas exceções, cineastas que pudessem cumprir o papel que ela queria: essa foi a ironia da época. Como a Embrafilme teria que passar ao financiamento de uma produção que fosse dita de qualidade, o esquema de produção ficou adiado. O governo não gostava da comédia musical do período que não era a chanchada mais inocente da primeira fase. Esta teve, entre I959 e I96I, seus últimos filmes de grande interesse, mas depois, em parte pela ascensão da TV, declinou. A comédia no final dos anos 60 foi progressivamente se erotizando em diálogo com uma faixa de público cativo. Isto não interessava ao governo. Em I974, no governo Geisel, começou o dito processo de abertura, lentíssima e gradual; a partir de então, abre-se a possibilidade da empresa estatal marcar o encontro com os cineastas do Cinema Novo, quando se constitui o período Embrafilme que financiou os filmes ditos de qualidade. É o momento em que o cinema brasileiro atinge o seu maior patamar, com 35\% do mercado - dos quais metade era a comédia erótica não financiada pela Embrafilme e a outra metade era dos filmes financiados, realizados por autores mais variados, do Ginema Novo até os mais jovens que foram se incorporando, e depois até o pessoal do Cinema Marginal, pois no fim dos anos 70 até o Júlio Bressane e o Rogério Sganzerla tiveram apoio da Embrafilme, mesmo com todas as brigas que aconteceram. Lá atrás, em I968-69, quando o pessoal do Ginema Novo decidiu se ajustar um pouco a fim de ampliar o seu público, Rogério e Bressane eram cineastas de destaque na geração mais jovem que recusou a adaptação ao mercado e continuou com um cinema agressivo, iconoclasta, que não queria pacto com o público, por supor que o espectador tem de ser provocado. Aquele período mencionado como o melhor do cinema brasileiro no mercado o é em função de uma conjuntura muito específica, em que havia um financiamento forte de capital de uma empresa e um sistema de distribuição - já que o superintendente de comercialização desta Embrafilme a partir de 1974 era o Gustavo Dahl, cineasta do Ginema Novo e também quem escrevia bastante sobre a economia do cinema no Brasil desde os anos 6o. Então, sempre há essa divisão: o cinema hegemônico vindo de Hollywood e outros centros de produção, e essa outra faixa ocupada pelo cinema brasileiro que se beneficia da legislação e da reserva de mercado. O Estado funciona em duas frentes: de um lado, como financiador 
e, de outro, como legislador que cria uma reserva de mercado para o filme brasileiro.

Ao longo dos anos 80, o esquema da Embrafilme começa a não funcionar mais, pois, na Nova República, a questão cultural é outra, com a mídia já em outro patamar de mercantilização; a televisão brasileira tinha efetivamente tomado conta, assumindo no Brasil um papel muito maior do que na grande maioria dos países; a hipertrofia da TV no Brasil é um fato muito particular e merece maior discussão. A Embrafilme foi, pelos erros e problemas que lhe eram próprios, se desgastando e no final dos anos 80 o sistema chegou ao ponto agudo de sua crise. Debilitado, recebeu o golpe de misericórdia de Collor, que extinguiu a Embrafilme e todo o sistema de financiamento existente. Ficamos sem um modelo de produção. Ora, com um cinema em crise e com toda essa dificuldade de inserção no mercado, não havia hipótese de um capitalista se dispor a investir em cinema e foi preciso vir a lei da isenção fiscal, em I994, pela qual a empresa, em vez de pagar imposto, pode carregar o dinheiro para a produção de filmes. O modo de produção atual é o do mecenato público mediado pelas empresas que ganham a imagem de patrocinadores sem efetivamente desembolsar dinheiro seu. Veja o caso da Globo Filmes: ela entra no sistema mas não entra com dinheiro, só com publicidade nas emissoras que já são janelas da Globo, criando o elo que permite ao produto chegar ao público. Além disto, os filmes feitos em parceria com a Globo trazem os atores de novela que facilitam essa ponte entre TV e cinema, e o resultado disso é que no cinema brasileiro alguns filmes são feitos para milhões, no esquema da Globo, e muitos filmes para 20, 50, IOO mil espectadores. O Estado brasileiro paga a conta e as empresas têm a vantagem da propaganda; os cineastas viabilizam os seus filmes que, quando prontos, não sofrem uma pressão do capital para a recuperação do investido. Fazer sucesso é uma questão simbólica de afirmação cultural e de legitimação social do modelo de produção existente. Viabilizar a produção é apenas a primeira etapa, pois há o problema da distribuição, longe de ser resolvido. A única vez que o governo Lula entrou em conflito com os conglomerados da mídia foi quando houve a tentativa de regulamentação de todo o audiovisual através da Ancinav. Recebendo fortíssima resistência com campanhas públicas que mobilizaram até os atores. Resultado: recuo total, na falta de apoio político prevaleceu o modelo de uma mídia desregulada num momento em que os filtros trazidos pelos que controlam a distribuição das imagens são mais hegemônicos do que jamais foram. É difícil hoje as pessoas imaginarem um sistema cultural sem esta presença central da esfera pública da televisão, como aconteceu, por exemplo, nos anos 50 e na primeira metade dos anos 60 no Brasil. O Cinema Novo, por exemplo, não pensou a questão da TV no início dos anos 6o; era outra a forma de circulação das imagens e da cultura, o que deu bastante visibilidade para os movimentos de politização 
da cultura. Ele foi criação de um grupo de jovens que abraçavam o cinema e a cinefilia em estreito contato com o clima geral de uma juventude universitária que atuava no movimento estudantil, fazia passeatas e via o cinema como um novo fator de formação para a vida e para a cidadania. Eu mesmo sou um produto disso, pois foi através dessa vida universitária que a minha cinefilia, e a de muitas outras pessoas da época, se constituiu. E não só os jovens, mas também os mais velhos, politizados e com formação universitária, constituíam o público do Cinema Novo, sem dúvida. A cinefilia hoje está menos politizada. Por exemplo, alterou-se completamente o sentido de um projeto nacional na esfera da cultura que favoreça a discussão política e a questão da transformação social, a menos que o projeto cultural esteja articulado com movimento sociais como o MST, por exemplo. Estamos vivendo um momento em que o processo de mercantilização de tudo está muito avançado, tornando a ideia de cultura alternativa algo exótico, cada vez mais à parte e invisível quando pensamos em termos das janelas tradicionais. O cinema sofre desta condição de algo "fora da norma" e muita gente me diz: esse cinema não deve ser bom, porque, se fosse, ele conseguiria competir. Porém, bom em que sentido? Quais são as características que esses filmes têm de ter para conseguirem sucesso? $\mathrm{O}$ mais eficaz, por enquanto, tem sido a parceria com a Globo e a adoção de modelos ficcionais já testados. O espectador brasileiro médio respeita a televisão brasileira e acha que é um produto que merece a sua atenção, sejam as novelas, seja o telejornalismo. Mas se sente divorciado do cinema e tende a olhá-lo com estranheza.

\section{Cinema político e cinema da política.}

Humanidades em DiÁlogo: Em "Sertão Mar", o senhor comenta a atitude dos artistas, não só do cinema, que buscavam intervir diretamente na vida política por meio da reflexão sobre a sociedade e a cultura brasileiras pela criatividade. $O$ senhor vê um distanciamento do cinema, das músicas, das artes em geral, de qualquer pretensão de modificar ou criticar a vida política brasileira atual? As relações entre arte, ideologia e política, hoje, estão mais frouxas?

Ismail XavieR: Estão efetivamente mais frouxas. Veja bem, não é só o cinema, a sociedade em geral hoje tem uma maneira de pensar a política que está constituindo um problema para a própria vida política. O sistema de representação está em crise. A grande discussão que estamos vendo é em torno dos problemas relacionados com a crise institucional, o Congresso e o significado das eleições, o significado da ideia de representação. Além disso, a política está sendo empregada segundo as regras do mercado. O caso mais típico 
foi o do Lula que, com todo o histórico dele, só foi eleito no momento em que assumiu o marketing o Duda Mendonça. Eu cito o Duda como o símbolo de todo um processo. O ajuste do PT ao jogo do mercado político é um problemão, mesmo na ótica de quem não passou para a oposição ao governo diante das óbvias contradições que estão sendo vividas nessas alianças todas que continuam pautando o processo político.

Voltando ao cinema, você tem o seguinte: a geração dos anos 60 viveu uma conjuntura em que o debate político supunha uma velocidade da História que se mostrou ilusória. Então, na minha geração se falava em processo de transformação como uma coisa muito rápida. Havia um senso de um poder de intervenção que estava não só nos cineastas e artistas, mas naqueles que abraçavam a política diretamente. Em todos os aspectos da vida, a juventude dos anos 60 viveu esse momento de uma convicção de ter um poder maior do que tinha e de pensar que um processo de cem anos poderia ser vivido em cinco ou dez. Depois daquela experiência, ficaram as interrogações. E hoje as pessoas pensam de forma diferente o que fazer com o cinema e de que maneira o cinema pode ter um papel na política ou intervir em um debate. Os cineastas hoje estão vivendo uma situação de quem já não tem mais um mandato popular. O cineasta dos anos 60 se via como um porta-voz da sociedade, ou das classes dominadas, alguém com um mandato que fazia filmes como quem falava em nome da nação. O que aconteceu de lá para cá foi um processo de transformação em que o cineasta perdeu esse senso de mandato e chegou a um ponto de se sentir pressionado a legitimar a sua atividade. $O$ cineasta brasileiro atual, antes de se colocar como porta-voz, pensa nos seus direitos de existência. Isso ocorre porque a produção se viabiliza a partir de um mecenato feito com dinheiro público e gestão privada dos investimentos, pela Lei do Audiovisual que pode mudar, dependendo da evolução da conjuntura. Para que ela se mantenha e continue viabilizando o cinema brasileiro, é preciso que esse cinema se legitime e evite pressões pela mudança do quadro legal.

Humanidades em Dí́logo: Ainda no âmbito da turbulenta relação do cinema com a política, tal relação parece sempre ter sido caracterizada mais por um desejo de proximidade do que repulsa. Chefes de Estado souberam incorporar o cinema à sua agenda política, criando uma relação ética peculiar entre o Estado e os filmes produzidos para exaltá-lo. Mesmo os filmes de protesto que não se aliavam ao regime vigente, o qual criticavam, tendiam à exaltação de outros regimes ou partidos. Para além da individualidade política, o cinema serviu como propaganda e exultação de Camaradas e Líderes da Nação, maquiando seus vícios e escondendo os horrores comandados por esses mesmos chefes, elevando-os ao papel de heróis do melodrama político. Recentemente, o diretor Fábio Barreto, do filme, "Lula, o filho do Brasil", 
declarou: "Estamos fazendo esse filme porque Lula é um herói". Tendo em vista que o filme será lançado no ano de eleições presidenciais, pode-se instantaneamente reportá-lo a essa tradição de aproximação entre o cinema e o poder. Como se poderia pensar uma relação do político com o cinema que não a de cega exaltação? O senhor vê com bons olhos o lançamento e o contexto do filme de Barreto?

ISMAIL XAVIER: O cinema é tanto mais forte na sua intervenção política quanto mais essa intervenção consiga se repor dentro da continuidade de um sistema de produção. Mais importante do que exemplos pontuais é a continuidade de um sistema de valores que se reafirma na maioria dos filmes, sejam de que gênero forem, seja explícita ou implicitamente, seja até por inércia. Ou seja, a política é tanto mais eficiente quanto mais ela estiver apoiada por um sistema de produção contínuo, não sendo aí decisiva a qualidade estética das obras. Hollywood é eficiente pela regra dos grandes números: poucos acertos compensam muitos erros. A televisão brasileira também, pois não é um programa isolado da Globo que conta, mas a continuidade ao longo de décadas que vai definindo uma cultura e vai fazendo a televisão intervir na maneira como as pessoas pensam os problemas da família, da vida econômica e da política. Os casos pontuais podem ter diferentes sentidos conforme o caso. Uma coisa é, no regime nazista, a Leni Riefenstahl participar de forma direta na vida política do partido, fazer o documentário do grande congresso de Nuremberg e a representação heróica do Hitler. Outra coisa é o John Ford fazer, em 1938, o Young Mr. Lincoln para exaltar o ex-presidente num certo momento da vida política do país. Outra coisa ainda é o Abel Gance, em I927 na França, fazer o Napoleão. Então, há um leque de situações em que alguém ou um sistema de produção resolve trabalhar com heróis fundadores e com a questão histórica da constituição da nação. O pressuposto é de que a nação precisa do mito e do discurso identitário; solicita a celebração dos pais fundadores ou das novas lideranças, ou pede também a construção de certo olhar para o passado que apresente os dados de sua formação. A biografia de um líder contemporâneo faz parte deste jogo, tal como aconteceu na Bolívia, onde já há filmes sobre Evo Morales. Aqui no Brasil aparece essa iniciativa dos Barreto. Ao que parece, haverá um gesto de alinhamento, de busca de criação de mito, o que é totalmente oposto ao que o João Salles fez no Entreatos e ao que o Coutinho fez no Peões. São dois filmes feitos com outros pressupostos e com uma postura, a meu ver, muito mais legítima, resultando em obras que permitem um diálogo produtivo para pensar muitos problemas. Esse filme produzido pelo Barreto fará parte do jogo eleitoral de 20IO, não sei bem em que direção, pois nunca se pode desprezar o dado de risco aí implicado. Dependendo do que resultar desse filme, ele pode não ser uma boa alavanca. 
Mas se for eficiente como produção de mito, talvez já seja preparação para as eleições de 20I4. Do ponto de vista do Lula e de muita gente que o apoia, a questão do cinema será sempre uma aposta, um campo de incertezas. A mim seria difícil antecipar o significado de um filme pelas intenções que o cercam. Eu posso até ter meus palpites e expectativas a respeito do filme, mas é preciso esperar para ver.

HumanidAdes EM DiÁlOGO: Mas se a intenção for fazer uma construção de um mito, de um herói, o senhor vê com bons olhos essa intenção?

ISMAIL XAVIER: Se for para fazer um Lula igual a Dois Filhos de Francisco, não vejo nenhum interesse em biografias desse tipo, seja um político, de um artista, de figura pública qualquer. A intenção enquanto tal não traz, para mim, nenhum interesse, nada de promissor.

Humanidades em DiÁlogo: E quanto à parte política da intenção de fazer um filme nesse espectro da criação de um mito no momento em que o biografado está exercendo a presidência?

ISMAIL XAVIER: Tem um lado até meio gauche, meio fora do lugar, supor que uma proposta como essa possa se legitimar diante de quem quer que seja. Mas não quero entrar numa discussão sobre um filme que eu não vi e que suponho estará empenhado em monumentalizar a figura, coisa problemática do ponto de vista do valor estético.

Humanidades em DiÁlogo: Não parece que isso só aparece em casos de governos, geralmente totalitários, que se mantêm às custas de um culto à personalidade?

ISMAIL XAVIER: Embora seja mais provável em sistemas totalitários, esta iniciativa também ocorre em outras situações; quem deveria estar preocupado com o fato é o próprio Lula, pois o filme pode ser uma grande munição para os seus opositores que batem na tecla de que a única coisa que sustenta o governo Lula é o próprio Lula e sua liderança carismática que se sobrepõe aos partidos, que se define na sua comunicação direta com o eleitorado, que tem estratégias de comunicação que confundem o debate político. Tudo que está em pauta na oposição pode ganhar muita munição com um filme como esse. A conjuntura é tal que nossa tendência é esperar uma postura convencional na construção de uma biografia: as etapas da vida, os dramas próprios a cada faixa etária, e a sucessão de experiências entendida como uma teleologia construtora de um indivíduo que tem as qualidades que o transformaram em um grande líder. 